\title{
Autosomal recessive Stickler syndrome
}

INSERM

\section{Source}

INSERM. (1999). Orphanet: an online rare disease and orphan drug data base. Autosomal recessive Stickler syndrome. ORPHA:250984

Autosomal recessive Stickler syndrome is a rare type of Stickler syndrome (see this term), found in one family to date, caused by a mutation in the COL9A1 gene, and like other dominantly inherited forms of the disease manifesting with opthalmological (myopia, retinal detachment and cataracts), orofacial (microg nathia, midface hypoplasia and cleft palate) auditory (sensorineural hearing loss) and articular (epiphyseal dysplasia) symptoms 